\title{
PERWUJUDAN ASAS KEADILAN DAN KESEIMBANGAN DALAM PEMBUATAN AKTA PERSEKUTUAN KOMANDITER BERDASARKAN AKAD MUDHARABAH
}

\author{
THE PRINCIPLE OF JUSTICE IN THE MAKING OF A LIMITED PARTNERSHIP BASED \\ ON MUDHARABAH CONTRACT
}

\author{
Momon Ardiansyah, Siti Hamidah, Dewi Astuti Mochtar \\ Program Studi Magister Kenotariatan Universitas Brawijaya \\ Jalan M.T. Haryono 168, Malang \\ email: momonardiansah1@gmail.com
}

\begin{abstract}
: this study discusses the creation and realization of the principle of justice and the balance of limited partnership deed (commanditaire vennootschap) based on mudharabah contracts. The method uses normative legal research to analyze the principle of justice in contracts based on mudharabah contracts on the formation of limited partnership through literature review and exploring positive laws that apply. The results show the principle of justice and balance in forming a limited partnership using the mudharabah contract is reflected if one form of cooperation is based on a sense of help and its implementation fulfills the principle of fairness both in determining profits, losses, and relating to the termination of the cooperation agreement.
\end{abstract}

Keywords: limited partnership, mudharabah contract, contract

\begin{abstract}
Abstrak: kajian ini membahas pembuatan serta perwujudan asas keadilan dan keseimbangan akta persekutuan komanditer (commanditaire vennootschap) berdasarkan akad mudharabah. Metode yang digunakan pada kajian ini adalah penelitian hukum normatif. Metode tersebut digunakan untuk menganalisis asas keadilan dalam perjanjian berdasar akad mudharabah pada pembentukan persekutuan komanditer melalui kajian kepustakaan dan menelusuri hukum positif yang berlaku. Hasil kajian menunjukkan bahwa asas keadilan dan keseimbangan dalam pembentukan persekutuan komanditer dengan menggunakan akad mudharabah tercermin apabila salah satu bentuk kerja sama dilandasi dengan rasa tolong menolong dan pelaksanaannya memenuhi asas keadilan baik dalam penentuan keuntungan, kerugian, dan berkaitan dengan berakhirnya perjanjian kerja sama.
\end{abstract}

Kata Kunci: persekutuan komanditer, akad mudharabah, perjanjian

\section{PENDAHULUAN}

Konsep bagi hasil dan kemitraan dapat dibagi menjadi dua jenis, yaitu mudharabah dan musyarakah. Dua konsep ini umum dilakukan di Indonesia dalam melakukan kerja sama yang berbentuk persekutuan komanditer (commanditaire vennootschap). Seiring meningkatnya kerja sama investasi dengan konsep kemitraan berbasis syariat baik itu akad mudharabah maupun musyarakah, pemerintah merespon secara positif dengan mengeluarkan berbagai aturan baru terkait kerja sama sistem ekonomi syariat. Salah satunya adalah penyelesaian sengketa dalam kegiatan ekonomi berdasarkan prinsip syariat diberi pilihan hukum untuk dapat beracara di pengadilan agama. Pemberlakuan asas keadilan dalam setiap tahapan kegiatan operasional akad persekutuan perdata sangat diperlukan untuk menghindari sengketa yang terjadi dalam kerja sama kemitraan dengan akad mudharabah maupun musyarakah.

Salah satu bentuk dari persekutuan perdata (maatschap) adalah persekutuan 
komanditer yang dalam hukum Islam disebut dengan istilah mudharabah. Dalam hukum perdata di Indonesia secara tegas juga dapat ditemukan pada Pasal 1618 Kitab Undang-Undang Hukum Perdata (KUH Perdata). Persekutuan komanditer adalah suatu persekutuan yang didirikan oleh satu orang atau beberapa orang yang mempercayakan uang atau barang kepada satu orang atau beberapa orang yang menjalankan perusahaan dan bertindak sebagai pemimpin. Pasal 19 Kitab Undang-Undang Hukum Dagang (KUHD) menyatakan bahwa perseroan komanditer adalah perseroan yang menjalankan suatu perusahaan, dibentuk antara satu orang atau beberapa orang pesero yang secara langsung bertanggung jawab untuk seluruhnya pada satu pihak dan satu orang atau lebih sebagai pelepasan uang pada pihak lain (Sembiring, 2004).

Titik awal dari kelancaran suatu usaha adalah kesepakatan yang terjadi dalam perjanjian di antara mitra usaha. Pada perjanjian tersebut tukar-menukar kepentingan mitra usaha terjadi. Perbedaan pendapat dalam memahami sebuah perjanjian kerja sama dapat menyebabkan sengketa usaha. Sengketa usaha sering kali berawal dari ketidakjelasan perjanjian yang menjadi landasan dari kerja sama. Gagasan baru dalam bisnis sangat diperlukan, misalnya dengan menghadirkan perjanjian berdasar konsep akad mudharabah sebagai landasan yang memberikan kepastian dan keadilan bagi seluruh pihak yang bekerja sama. Islam selalu mengajarkan bahwa hukum harus adil agar tidak terjadi masalah di kemudian hari.

Akad mudharabah sebagai salah satu produk berdasarkan kemitraan yang dapat dipergunakan dalam membentuk kerja sama dalam bentuk persekutuan komanditer menjadi tema sentral dalam kajian ini. Masalah utamanya adalah bahwa sampai saat ini pengaturan persekutuan komanditer hanya diatur dalam Pasal 19, 20, dan 21 KUHD yang ketentuannya belum mengatur secara rinci tentang pembentukan persekutuan komanditer berdasarkan akad mudharabah. Fakta empiris yang terjadi di masyarakat, kerja sama dalam bentuk persekutuan komanditer masih diminati karena proses pembentukan kerja sama dalam persekutuan komanditer cukup mudah dan memerlukan modal yang tidak terlalu besar.

Masalah selanjutnya adalah proses pembuatan persekutuan komanditer. Akta persekutuan komanditer dapat dibuat oleh atau di hadapan notaris, yaitu berkaitan dengan pembuatan akta pendirian persekutuan komanditer, akta perubahan anggaran dasar persekutuan komanditer, dan akta pembukaan cabang persekutuan komanditer. Pendirian persekutuan komanditer tidak memerlukan formalitas tertentu sehingga dapat dilakukan secara tertulis maupun lisan. Akta dapat berupa akta autentik atau di bawah tangan. Tidak ada keharusan untuk melakukan pendaftaran dan pengumuman dalam Berita Negara Republik Indonesia ketika persekutuan komanditer didirikan. Namun, pembuatan akta pendirian persekutuan komanditer pada saat ini harus menggunakan akta autentik. Hal itu dilakukan untuk mewujudkan kepastian hukum ketika suatu perjanjian kerja sama dibentuk.

\section{METODE}

Kajian ini menggunakan pendekatan hukum normatif. Penelitian hukum normatif merupakan proses untuk menemukan aturan hukum guna menjawab permasalahan hukum untuk menghasilkan argumentasi, teori, atau konsep baru sebagai penilaian dalam masalah yang terjadi (Marzuki, 2016). Penelitian hukum normatif tersebut digunakan untuk menganalisis asas keadilan dalam perjanjian berdasar akad mudharabah pada pembentukan persekutuan komanditer. Penelitian normatif seringkali disebut dengan penelitian doktrinal, yaitu penelitian yang objek kajiannya adalah dokumen peraturan perundang-undangan dan bahan pustaka (Soejono \& Abdurahman, 2003). 
Langkah awal yang dilakukan adalah dengan melakukan kajian terhadap asas-asas keadilan dalam perjanjian berdasarkan akad mudharabah pada pembentukan persekutuan komanditer. Langkah selanjutnya ialah mencontohkan model perjanjian yang menggunakan dua sistem hukum, yakni hukum Islam dan hukum perdata yang berlaku di Indonesia, serta kepentingan yang menyertai pada dua model perjanjian tersebut, baik kepentingan dari penanam modal maupun kepentingan dari pengelolanya.

Kajian ini didasarkan pada bahanbahan hukum yang bersifat normatif yaitu berupa peraturan hukum positif nasional dan hukum Islam yang merupakan bagian dari hukum positif yang tidak dapat dipisahkan. Berdasarkan kekuatan mengikatnya, hukum tersebut diklasifikasikan sebagai bahan hukum primer, bahan hukum sekunder dan bahan hukum tersier (Soekanto, 1986). Bahan hukum primer yaitu bahan hukum yang mempunyai kekuatan mengikat. Bahan hukum sekunder yang dipergunakan yaitu literatur, buku-buku, jurnal hukum, pendapat sarjana, penelitian terdahulu, makalah, serta situs internet yang berkaitan dengan persekutuan komanditer. Bahan hukum tersier yang digunakan sebagai petunjuk atau penjelasan bahan-bahan hukum primer dan sekunder yang digunakan adalah kamus bahasa Indonesia, kamus bahasa Inggris, kamus hukum, ensiklopedia, serta sumber lain yang berhubungan dengan penulisan ini.

\section{HASIL DAN PEMBAHASAN}

\section{Konsep Perjanjian Pembentukan Persekutuan Komanditer Menggunakan Akad Mudharabah Berdasarkan Asas Keadilan dan Keseimbangan}

Bagian-bagian dari perjanjian untuk pembentukan persekutuan komanditer berdasarkan akad mudharabah terdiri dari tiga bagian, yaitu pendahuluan, isi akad, dan ketentuan umum. Bagian pendahuluan berisi identitas mitra, alasan kedatangan, sesuatu yang kehendaki, dan sebagainya. Pada pendahuluan terdiri atas dua klausul, yaitu klausul subbagian pembuka dan klausul identitas mitra perjanjian kerja sama. Pada klausul bagian pembuka, sama halnya dengan pembuatan awal akta autentik perjanjian pendirian persekutuan yang terdiri atas: judul akta, nomor akta, pukul, hari, tanggal, bulan dan tahun, serta nama lengkap dan tempat kedudukan notaris. Sedangkan pada klausul identitas para mitra berisi komparisi yaitu salinan yang berasal dari bahasa Belanda comparitie yang berarti tindakan menghadap dalam hukum atau di depan seorang notaris atau pejabat umum. Orang yang menghadap notaris dinamakan penghadap (Kadiman, 1971).

Pada perjanjian hukum Islam, identitas para pihak ini terkait dengan rukun dan syarat perjanjian. Hal ini tidak jauh berbeda dengan hukum positif pada umumnya. Mengenai syarat dan rukun perjanjian, para penganut mazhab berbeda pendapat. Penganut mazhab Hanafi berpendapat bahwa rukun perjanjian hanya perlu ijab kabul (sighat al- 'aqd), syarat perjanjian yang disepakati oleh subyek perjanjian (al'Aqidain) dan obyek perjanjian (mahallul ' $a q d$ ). Dimasukkannya subyek dan obyek perjanjian dalam syarat perjanjian menurut mazhab ini karena keduanya bukan bagian dari perbuatan hukum perjanjian (Mas'adi, 2002).

Bagian isi akad mudharabah memuat hal yang dikehendaki, berupa hak dan kewajiban termasuk pilihan penyelesaian sengketa yang disebut dengan pasal. Pasal merupakan bagian dari perjanjian yang terdiri atas kalimat-kalimat yang berisi tentang situasi dan suatu hal yang disepakati dapat berbentuk tersurat maupun tersirat. Ada tiga klausul yang tercantum dalam bagian isi akad mudharabah, yaitu klausul definisi, klausul transaksi, dan klausul spesifik. Klausul definisi adalah pasal yang mengatur tentang berbagai definisi, interpretasi, maupun konstruksi dalam 
perjanjian. Klausul transaksi (operative language) yaitu klausul yang berisi jumlah dana yang disepakati, tujuan kerja sama, dan pembagian keuntungan dan kerugian pada akad mudharabah. Kemudian klausul spesifik, yaitu hal-hal yang terperinci dalam suatu transaksi. Klausul merupakan pengaman bagi pelaksanaan akad kerja sama. Beberapa jenis klausul spesifik antara lain agunan dalam akad mudharabah, jenis usaha yang akan dilakukan para mitra, klausul condition precedent pada akad mudharabah, klausul affirmative covenant dan klausul negative covenant pada akad mudharabah, bagian terakhir adalah pengawasan dan pengamanan akad mudharabah.

Klausul ketentuan umum berisi tentang domisili hukum, penyelesaian sengketa, pilihan hukum, pemberitahuan, keseluruhan dari perjanjian, dan lain-lain. Klausul ini dapat berupa klausul arbritase dan klausul penutup pada akad mudharabah. Klausul arbitrase merupakan klausul yang wajib ada dalam setiap akad. Hal ini untuk memudahkan dalam menyelesaikan permasalahan jika dalam akad terjadi perselisihan antara para pihak mitra yang bekerja sama. Kemudian yang terakhir adalah klausul penutup pada akad mudharabah. Pada bagian penutup terdiri atas dua bagian, yaitu kata penutup dan penempatan tanda tangan. Kalimat penutup menjelaskan tentang perjanjian tersebut dibuat dan ditandatagani oleh pihak-pihak dengan menyebutkan nama pihak yang terlibat, para pihak menyatakan ulang bahwa mereka akan terikat dengan perjanjian, serta menerangkan tentang tempat penandatanganan perjanjian.

\section{Perwujudan Asas Keadilan dan Keseimbangan dalam Perjanjian Pembentukan Persekutuan Komanditer Berdasarkan Akad Mudharabah \\ Perwujudan keadilan selalu terkait dengan distribusi yang ada di dalam kehidupan masyarakat (Rahardjo, 2006b). Pendistribusian keadilan ini tidak selalu bersifat fisik tetapi juga non fisik (intangible) seperti barang,}

jasa, modal usaha, kedudukan, peran sosial, kewenangan, kekuasaan, kesempatan, dan lain-lain yang memiliki nilai-nilai tertentu bagi kehidupan manusia, begitu juga dengan keadilan yang ada di dalam agama Islam.

Keadilan di dalam agama Islam memiliki kedudukan yang sangat penting. Konsep keadilan tersebut tercantum di dalam ayat Al-Qur'an. Salah satu nama Allah yang ke-30 dari al-Asma al-Husna, ada istilah tentang keadilan yaitu $a l-A d l$. Begitu juga dalam pembentukan persekutuan komanditer dengan menggunakan akad mudharabah harus mengandung keadilan yang tercermin dalam proporsionalitas dan keseimbangan. Pada dasarnya asas keseimbangan dan asas proporsionalitas tidak dapat dipisahkan keberadaannya dalam perjanjian.

Untuk membedakan keduanya, pertama dapat ditelusuri dari makna leksikal di antara kedua istilah tersebut, yaitu makna keseimbangan dan proporsional. Dalam beberapa kamus terhadap dua istilah tersebut ada yang membedakan arti, namun juga ada yang menyamakannya. Pengertian asas keseimbangan lebih abstrak pemahamannya dibandingkan asas proporsionalitas. Untuk memudahkan pemahaman antara kedua asas tersebut dapat ditelusuri melalui pendapat para sarjana, karakteristik, maupun daya kerjanya (Rahardjo, 2006a).

Asas keseimbangan dan proporsionalitas dalam pembentukan persekutuan komanditer dengan menggunakan akad mudharabah dapat tercermin jika salah satu bentuk kerja sama dilandasi oleh rasa tolong-menolong. Sebagai contoh, ada seseorang yang mempunyai modal tetapi tidak mempunyai keahlian dalam menjalankan perusahaan dan sebaliknya. Ada seseorang yang mempunyai keahlian dan waktu, tetapi tidak mempunyai modal. Dengan demikian, apabila ada kerja sama dalam memajukan perekonomian, maka kedua belah pihak akan mendapatkan keuntungan modal dan keahlian yang dipadukan menjadi satu (Hasan, 2003). Berdasarkan uraian tersebut, maka dapat 
disimpulkan bahwa akad mudharabah berlaku antara dua pihak secara langsung, yaitu shahibul mal (pemilik modal) yang berhubungan langsung dengan mudharib (pemilik keahlian/pengelola). Oleh karena itu, dalam perjanjian pembentukan persekutuan komanditer berdasarkan akad mudharabah harus mengandung keadilan yang terefleksi dalam proporsionalitas dan keseimbangan.

Dalam pembentukan persekutuan komanditer berdasarkan akad mudharabah, proporsionalitas dan keseimbangan bagi para mitra yang akan mengadakan perjanjian merupakan bagian dari asas keadilan yang harus mencakup keadilan dalam sifat modal dan penentuan keuntungan serta kerugiannya. Sifat modal dalam akad mudharabah harus jelas jumlahnya. Apabila modal berbentuk barang, maka harus dihargakan dengan harga semasa dalam bentuk uang. Modal harus dalam bentuk tunai dan bukan piutang. Modal diberikan kepada mudharib untuk digunakan usaha. Terkait dengan modal, hukum perdata di Indonesia menyebutkan sebagai inbreng, yang secara eksplisit terdapat dalam Pasal 1619 KUH Perdata. Sejalan dengan hukum Islam, Pasal 1619 KUH Perdata memberikan keleluasaan bagi modal yang akan dimasukkan ke dalam persekutuan. Secara eksplisit, hukum perdata mengatur bahwa inbreng yang dapat dijadikan modal untuk membentuk persekutuan adalah uang, barang-barang, dan kerajinan.

Kerugian ditanggung pemodal, dengan syarat pihak pengelola tidak melakukan kelalaian dan kesalahan dalam menjalankan usaha. Tenaga dan waktu yang telah dikeluarkannya merupakan kerugian pihak pengelola. Pihak pemodal berhak mendapat keuntungan dari harta atau modal yang diberikan, dan pihak pengelola mendapat keuntungan dari tenaga dan waktu. Berakhirnya kerja sama berdasarkan akad mudharabah pada prinsipnya tidak pasti dan tidak terbatas, tetapi semua pihak berhak untuk menentukan jangka waktu.
Akad mudharabah dapat berakhir karena beberapa hal, antara lain: (a) pembatalan, larangan berusaha, dan pemecatan, (b) salah seorang aqid meninggal dunia, (c) salah seorang aqid gila, dan (d) modal rusak di tangan pengusaha.

Istihsan sebagai upaya pembaruan dalam perjanjian pembentukan persekutuan komanditer berdasarkan akad mudharabah harus disesuaikan dengan situasi dan kondisi. Karena Al-Qur'an dan sunnah terbatas, maka tidak semua persoalan dapat dijawab oleh Al-Qur'an dan sunnah. Sementara semakin lama semakin banyak persoalan yang muncul. Untuk menyelesaikan persoalan yang muncul, maka ulama-ulama melakukan ijtihad (Haq, 1997). Hasil ijtihad benar atau salah tidak ada yang menilai, untuk itu diperlukan ijma' sebagai parameter dalam menguji kebenaran hasil ijtihad karena yang diambil secara kolektif jauh lebih kuat dibanding dengan yang dibuat secara individu (Usman, 1994).

Kondisi seperti itu tidak dapat lagi dipertahankan, karena kekuasaan Islam semakin luas dan terpencarnya para ulama, maka ijma' tidak mungkin dilakukan lagi. Akhirnya masing-masing ulama melakukan istinbath hukum sendiri. Maka lahirlah berbagai macam metode istinbath hukum. Seperti metode qiyas, istihsan, istislah, 'urf, istishab, dan lain sebagainya. Metodemetode istinbath hukum seperti itulah yang menjadi obyek pembahasan ushul fikih (Zahrah, 2000).

Dalil-dalil syara' yang dijadikan sebagai sumber hukum bagi para mujtahid masing-masing berbeda. Imam Abu Hanifah menjadikan dalil-dalil syara ' yaitu: Alqur'an, sunnah, ijma' sahabat, qiyas, istihsan dan 'urf. Mazhab Maliki berpegang kepada Alqur'an, sunnah, ijma' ahlul Madinah, fatwa sahabat, khabar ahad dan qiyas, istihsan, istislah dan sadd al-zara'i, mura'at khilaf almuj-tahidin, istishab dan syar'u man qablana. Sedangkan dalil-dalil syara' yang dipegang oleh mazhab Syafi'i adalah 
Alqur'an, sunnah, ijma', qiyas, istislah, dan istishab. Ahmad bin Hanbal berpegang pada Alqur'an, sunnah, fatwa sahabat, dan qiyas (Zahrah, 2000).

Ibn Al-Arabi menjelaskan bahwa istihsan adalah meninggalkan kehendak dalil dengan cara pengecualian atau memberikan rukhsah karena berbeda hukumnya dalam beberapa hal (Asmawi, 2011). Sesuai dengan topik kajian ini, metode istihsan digunakan dalam dua pengkajian yaitu pengkajian makro dan pengkajian mikro. Pengkajian yang bersifat mikro, kajian ini difokuskan pada hubungan hukum para mitra yang terlibat di dalam kerja sama persekutuan komanditer berdasarkan akad mudharabah. Pengkajian secara makro digunakan dalam mengkaji pembentukan persekutuan komanditer berdasarkan akad mudharabah dari sisi filosofis, sisi yuridis dan sosiologis.

Unsur filosofis ini dapat diketahui dari adanya keadilan substantif yang meliputi pembagian keuntungan dan kerugian, prosedur memasukkan modal, dan berakhirnya kerja sama persekutuan komanditer berdasarkan akad mudharabah yang dituangkan dalam perjanjian tertulis yang disusun dan disepakati oleh para pihak yang akan mengadakan kerja sama. Terkait dengan sisi yuridis, ditemukan bahwa pengaturan persekutuan komanditer di Indonesia diatur dalam Kitab Undang-Undang Hukum Dagang, Kitab Undang-Undang Hukum Perdata, dan untuk pendaftaran persekutuan komanditer diatur dalam Peraturan Menteri Hukum dan Hak Asasi Manusia Republik Indonesia Nomor 17 Tahun 2018 tentang Pendaftaran Persekutuan Komanditer, Persekutuan Firma, dan Persekutuan Perdata.

Berdasarkan unsur sosiologis, dapat diketahui bahwa KUH Perdata dan hukum Islam terdapat pertentangan yaitu pada Pasal 1633 KUH Perdata yang memperbolehkan keuntungan dinikmati salah satu pihak. Hal ini terlihat pada pembagian keuntungan jika seorang mitra hanya dapat memberikan keahliannya saja tanpa adanya modal. Dalam hukum Islam hal ini sangat dilarang. Pada akad mudharabah pihak pemodal berhak mendapat keuntungan dari harta atau modal yang dikeluarkannya, dan pihak pengelola mendapat keuntungan dari tenaga dan waktu yang dikeluarkannya.

\section{SIMPULAN}

Pembuatan akta persekutuan komanditer berdasarkan akad mudharabah belum diatur di dalam hukum dagang maupun hukum perdata. Pembuatan akta persekutuan komanditer berdasarkan akad mudharabah, harus mencakup proporsi keadilan dan keseimbangan modal, proporsi keuntungan dan kerugian. Asas keseimbangan dan asas proporsionalitas dalam pembentukan persekutuan komanditer dengan menggunakan akad mudharabah dapat tercermin apabila bentuk kerja sama dilandasi dengan rasa tolong-menolong. Pihak pemodal berhak mendapat keuntungan dari modal yang dikeluarkan dan pihak pengelola mendapat keuntungan dari tenaga dan waktu yang dikeluarkan.

\section{DAFTAR RUJUKAN}

Asmawi. (2011). Perbandingan Ushul Fiqh. Jakarta: Amzah

Haq, H. (1997). Dialog Pemikiran Islam Ujung Pandang (Cetakan I). Ujung Pandang: Yayasan AHKAM.

Hasan, M. A. (2003). Berbagai Macam Transaksi dalam Islam (Fiqh Muamalat). Jakarta: PT Raja Grafindo Persada.

Kadiman, R. (1971). Akte Akte Notaris Dengan Tjatatan-Tjatatan, Djilid 1. Jakarta

Marzuki, P. M. (2016). Penelitian Hukum Edisi Revisi. Jakarta: Kharisma Putra Utama.

Mas'adi, A. G. (2002). Fiqih Muamalah Konstektual. Jakarta: Raja Grafindo Persada. 
Rahardjo, S. (2006a). Hukum Dalam Jagat Ketertiban. Jakarta: UKI Press.

Rahardjo, S. (2006b). Ilmu Hukum. Bandung: PT. Citra Aditya Bakti.

Sembiring, S. (2004). Hukum Dagang. Bandung: PT. Citra Aditya Bakti.

Soejono, \& Abdurahman. (2003). Metode Penelitian Hukum. Jakarta: Rineka Cipta.
Soekanto, S. (1986). Pengantar Penelitian Hukum. Jakarta: UI Press.

Usman, I. (1994). Istihsan dan Pembaharuan Hukum Islam (Cet. I). Jakarta: Raja Grafindo.

Zahrah, M. A. (2000). Ushul al-Fiqh, diterjemahkan oleh Saefullah Ma'sum dengan judul Ushul Fiqih (Cet. VI). Jakarta: Pustaka Firdaus. 